\title{
Impact of volcanic ash deposition on foliar productivity and insect herbivory in northern Patagonia deciduous forests
}

\author{
Enrique J. Chaneton ${ }^{1, \bowtie}$; Noemí Mazía ${ }^{2}$; Lucas A. Garibaldi ${ }^{3,4}$; Jaquelina Chaij ${ }^{2}$ \& \\ THOMAS KitZBERGER ${ }^{4}$
}

1. IFEVA-CONICET and Facultad de Agronomía, Universidad de Buenos Aires, Buenos Aires, Argentina. 2. Departamento de Producción Vegetal, Facultad de Agronomía, Universidad de Buenos Aires, Buenos Aires, Argentina. 3. Sede Andina, Universidad Nacional de Río Negro and CONICET, Bariloche, Argentina. 4. INIBIOMA-CONICET and Laboratorio Ecotono, Universidad Nacional del Comahue, Bariloche, Argentina.

\begin{abstract}
Aвstract. Volcanism has been a major force shaping the dynamics of Andean landscapes during the Holocene. Yet we still know little about the consequences of modern volcanic events on forest functioning. Ash fall may elicit multiple direct and indirect effects on key ecosystem attributes, with disturbance severity likely varying with distance to the crater. We examined the impact of ash deposition on foliage productivity and insect herbivory after the 2011 eruption of the Volcán Puyehue-Cordón Caulle system, in Nothofagus pumilio forests of northern Patagonia, Argentina. Tree leaf litterfall, a surrogate for annual foliar production, was measured before and after the event in wet and dry forest sites, which were located $22 \mathrm{~km}$ and $80 \mathrm{~km}$ east from the crater and were affected by mass deposition of coarse- and fine-grained tephra, respectively. Leaf damage by insects was monitored over a 10-year span (2004-2013) including the volcanic event. Foliar productivity in 2012 dropped by $60 \%$ in the wet forest, but did not change in the dry forest. Leaf area damaged by insects decreased abruptly in 2012, with post-eruption herbivory levels falling outside the range of annual variation recorded before the event. The impact was most severe in the dry forest wich normally supports the highest endemic herbivory. In contrast, leaf damage remained high in another dry forest located $98 \mathrm{~km}$ southeast from the crater and little affected by ashfall. Changes in foliar production and insect herbivory persisted for two years after the event. Our results show a widespread disruption of canopy-herbivore interactions in areas heavily affected by tephra. Remarkably, volcanic ash acted as a broad-spectrum insecticide on canopy herbivores. In the short-term, ashfall constrained the energy flow through the forest canopy and the arthropod consumer community, and thus temporarily overwhelmed previously existing differences in productivity and herbivory between wet and dry forest habitats.
\end{abstract}

[Keywords: Canopy insects, disturbance, herbivory, long-term study, Nothofagus pumilio, productivity, volcanism]

\begin{abstract}
RESUMEN: Impacto de la deposición de ceniza volcánica sobre la productividad foliar y la herbivoría por insectos en bosques deciduos del norte de la Patagonia: El vulcanismo ha moldeado la dinámica de los paisajes andinos durante todo el Holoceno. Sin embargo, aún se conoce poco sobre las consecuencias de eventos volcánicos modernos en el funcionamiento de los bosques nativos. La caída masiva de cenizas puede generar múltiples efectos directos e indirectos sobre procesos clave del ecosistema. Aquí evaluamos el impacto de la deposición de cenizas emitidas por la erupción del complejo Volcán Puyehue-Cordón Caulle en junio de 2011, sobre la productividad foliar y la herbivoría por insectos del dosel en bosques de Nothofagus pumilio del norte de la Patagonia Argentina. La producción de hojas fue medida antes y después de la erupción, en bosques húmedos y secos situados a 22 y $80 \mathrm{~km}$ del volcán y afectados por la caída de pumicita gruesa y fina, respectivamente. El área foliar dañada por insectos fue monitoreada durante 10 años (2004-2013), incluyendo al evento volcánico. La productividad foliar en 2012 cayó un 60\% en el bosque húmedo pero no cambió en el bosque seco. El daño foliar se redujo abruptamente en 2012; los niveles de herbivoría post-erupción cayeron por debajo del rango de variación interanual registrado antes de la erupción. El impacto fue más severo en el bosque seco, donde los niveles endémicos de herbivoría son más elevados. En cambio, la herbivoría se mantuvo elevada en otro bosque seco localizado a $98 \mathrm{~km}$ del cráter y que recibió pocas cenizas. Los cambios en productividad y herbivoría persistieron por dos años después del evento. Estos resultados muestran una fuerte disrupción de las interacciones planta-herbívoro en áreas boscosas afectadas por la erupción volcánica. Las cenizas actuaron como un biocida de amplio espectro sobre los insectos defoliadores. En el corto plazo, la deposición de cenizas limitó el flujo de energía a través del dosel arbóreo y hacia los consumidores artrópodos.
\end{abstract}

[Palabras clave: Disturbios, estudio de largo plazo, herbivoría, insectos defoliadores, Nothofagus pumilio, productividad, vulcanismo]

Editora asociada: Adriana Ruggiero 


\section{INTRODUCTION}

Large-scale natural disturbances such as severe fires, floods, hurricanes, landslides and volcanic eruptions have been traditionally assumed to exert devastating, long-lasting effects on terrestrial ecosystems. More recently, the catastrophic view of a slowly recovering system on a denuded, lifeless landscape has been tempered by the recognition that even the most severe events create spatially heterogeneous, non-lethal conditions that facilitate recovery by a variety of organisms (Franklin et al. 1995; Turner et al. 1997; Dale et al. 2005). This fresh perspective emphasises the short-term response (or resistance) of ecosystems after major disturbances. Importantly, responses from organisms at different trophic levels will impinge on various ecosystem functions (Wardle 2002; Hartley \& Jones 2004). Changes in key process rates (e.g., primary production, herbivore consumption, litter fall, decomposition) will in turn propagate to affect biotic communities through networks of direct and indirect effects (Tylianakis et al. 2008).

Disturbances produced by volcanic activity have been studied in forested landscapes like Mount St. Helens in the Pacific Northwest, USA (Franklin et al. 1995; Zobel \& Antos 1997; Fagan \& Bishop 2000; Dale et al. 2005; Yang et al. 2011). Volcanic eruptions create centrifugal patterns associated with the radial nature of the explosive blast, ejection of hot debris and gases, and deposition of air-borne tephra (i.e., rock debris including gravel, sand-sized pumice and fine-grained ashes) over areas in excess of $10^{5} \mathrm{~km}^{2}$ (Dale et al. 2005). Studies have documented the destructive effects of debris avalanches, lava and mudflows on the flanks of volcanoes. The main focus has been on the primary succession initiated on newly exposed substrates and the long-term patterns of recovery of plant and animal assemblages (e.g., Zobel \& Antos 1997; Dale et al. 2005; Parmenter et al. 2005). For instance, in South America, Veblen (1985) studied the successional dynamics of Nothofagus forests on volcanic substrates in the Chilean Lake District. By contrast, impacts on forest ecosystems away from the 'blast zone' (where trees were either removed or killed), and across the wider 'tephra-fall zone' affected by pumice and ash deposits, have been relatively little explored (Seymour et al. 1984; Antos \& Zobel 2005). Ash fall on distant forest canopies and soils may disrupt species interactions and ecosystem- level processes like primary productivity and herbivory (Bishop et al. 2005; Marske et al. 2007).

Ash fall may induce a number of direct and indirect effects on individual tree growth and forest productivity (Yamaguchi 1983; Hinckley et al. 1984; Segura et al. 1995; Biondi et al. 2003; Lawrence 2005). Deposition of pyroclastic debris may cause partial crown dieback, leading to short-term decreases in foliage production (see Lawrence 2005) and tree-ring growth (Segura et al. 1995; Biondi et al. 2003). In addition, ash-covered foliage shows altered energy and water balances, which may cause premature leaf senescence (Seymour et al. 1984). On the other hand,tephra can also indirectly affect tree growth and foliar production, for instance, by improving soil moisture conditions through decreased evaporation (Black \& Mack 1986) or enhanced nutrient availability (Dahlgren et al. 2004). Further, volcanic ash may release trees from insect defoliators (Marske et al. 2007), potentially increasing photosynthetic leaf area and canopy productivity (Schowalter 2000).

Effects of volcanic disturbance on insect communities may be complex, being dependent on species life-history traits (Schowalter 2000; Marske et al. 2007), trophic position (Parmenter et al. 2005), and timing of ashfall relative to insect phenology. Species pupating in the soil may become buried by thick ash layers, undergoing drastic population declines of unknown duration (Parmenter et al. 2005; Bishop et al. 2005). Herbivorous insects are expected to be negatively affected because of the loss of habitat and food resources (Bishop et al. 2005), and the physical impact of fine ashes on exoskeletons and feeding activity (Edwards \& Schwartz 1981; Buteler et al. 2011). As a result, an overall decrease in insect herbivory levels would be expected. However, folivores that find refuge from ashfall might then exert a greater consumptive impact on stressed host plants (Schowalter 2000), particularly if they are temporarily released from their own natural enemies (Hunter \& Price 1992; Bishop et al. 2005). How these multiple effects play out after major eruptions remains poorly understood, as few studies have addressed the impact of volcanic disturbances on forest insect herbivory (Marske et al. 2007).

Evaluating the impacts of volcanic events bear logistic limitations inherent to all natural 
experiments (Stewart-Oaten et al. 1986). The observational nature of such studies clearly reduces the ability to establish causal relations. In general, one relies on 'Before-After' and (or) 'Control-Impact' information, also known as BACI designs (Stewart-Oaten et al. 1986; Underwood 1992). However, lack of long-term records before the event implies that there is usually no information on base-line conditions to evaluate a shift in the system's behaviour (Smith 2011; Kitzberger 2012). This makes it difficult to assess disturbance effects within appropriate envelopes of natural variability for the attribute of interest (Underwood 1992; Smith 2011). Morover, it is often problematic to designate control sites that remained unaltered by the event, but are otherwise comparable to impact sites (Stewart-Oaten et al. 1986; Underwood 1992). The scale and rarity of volcanic events also imply that replication of impact and control sites may be missing. Thus, BACI designs may not be always feasible, especially if a large-scale event is expected to hit long-term study sites, while leaving comparable sites untouched (e.g., Spiller \& Schoener 2007). When prior data are available, they provide a rare opportunity to document changes induced by major perturbations (Lindenmayer et al. 2010).

In this study, we examine the impact of volcanic ash fall on two ecosystem processes, foliage production and insect herbivory, after the 2011 eruption of the Volcán Puyehue-Cordón Caulle (VPCC) system, in Nothofagus pumilio subalpine forests of northern Patagonia, Argentina. Volcanism has been integral to the geologic history of subantarctic Andean landscapes during the Holocene. The region has been repeatedly struck by large volcanic eruptions that shaped the dynamics of Nothofagus forests (Veblen 1985). The VPCC system erupted four times over the last century, yet the June 2011 event was the largest on record (Bermúdez \& Delpino 2011). Several hundred million tons of volcanic tephra were dispersed over $\sim 25000$ $\mathrm{km}^{2}$ along a west-to-east gradient (Gaitán et al. 2011), which comprised a directional shift in ash-grain size and thickness of tephra deposits (i.e., a proxy for disturbance 'intensity', sensu White \& Pickett 1985). We assumed that the 'severity' of the event (i.e., its impact on focal ecosystem attributes) would vary with distance to the crater.

Specifically, we expected 1) a decrease in current-year foliar productivity for $N$. pumilio wet forests located near the crater, because of the deleterious effect of tephra on tree canopies. In contrast, foliar production would be less affected in drier N. pumilio forests at greater distances from the crater. In addition, we expected 2) a decrease in foliage consumption by insect herbivores through ashfall effects on forest canopies and soils. This effect would be stronger in dry forests away from the crater, which support chronically higher folivory levels (Mazía et al. 2004, 2012; Garibaldi et al. 2010). Here, we use foliar productivity and insect folivory data collected before and after the 2011 eruption in forest sites differentially affected by ashfall. We report two years of post-eruption productivity and herbivory levels to provide an early evaluation of functional recovery.

\section{MATERIALS AND METHODS}

\section{Study design and rationale}

We used two complementary approaches to examine the potential effects of volcanic tephra on N. pumilio forest canopies in the aftermath of the 2011 VPCC eruption. Firstly, we compared forest sites with known habitat features that were differentially affected by the volcanic event due to their spatial location relative to the crater (Table 1 ; Figure 1). In this context, sites with little ash deposition may serve as 'controls' for evaluating the significance of post-eruption changes in process rates recorded in sites affected by different amounts and types of tephra. A similar approach was used by researchers working after the 1980 eruption of Mount St. Helens (Dale et al. 2005). In our case, this comparative design was enhanced by having before vs, after eruption measures for the control and impact sites (Stewart-Oaten et al. 1986; Underwood 1992). For clarity, we refer to this approach as 'spatial analysis' and use it to evaluate changes in annual foliar production and insect herbivory.

Secondly, we benefited from an ongoing study on the dynamics of insect herbivory (2004-2011) being conducted in dry and wet $N$. pumilio forests affected by heavy ash fall. This dataset provided a base-line condition against which post-eruption records could be compared (Smith 2011; Kitzberger 2012). We expected post-eruption herbivory levels to deviate away from the range of values recorded before the event for a given forest site. This approach will be referred to as 'temporal analysis' and will focus on annual changes in insect herbivory. Notice that, despite the added value of combining both these approaches, other limitations inherent to this type of study (e.g., replication level, covarying factors, etc.) suggest that establishing causality may not be strictly possible. Thus, interpretation of observed patterns must remain cautious. 
Table 1. Study sites and datasets used to evaluate the impact of the June 2011 volcanic eruption on foliage productivity and canopy insect herbivory in subalpine forests of northern Patagonia, Argentina. All three sites were representative of monospecific, Nothofagus pumilio forests.

Tabla 1. Sitios de estudio y series de datos utilizados para evaluar el impacto de la erupción volcánica de junio de 2011 sobre la productividad foliar y la herbivoría por insectos del dosel en bosques subalpinos del norte de la Patagonia, Argentina. Los tres sitios fueron representativos de bosques monoespecíficos de Nothofagus pumilio.

\begin{tabular}{|c|c|c|c|c|c|}
\hline Site name & Location $^{1}$ & Habitat type $^{2}$ & Volcanic tephra $^{3}$ & Herbivory $^{4}$ & Productivity \\
\hline Paso Puyehue & $40^{\circ} 43^{\prime} \mathrm{S}, 71^{\circ} 54^{\prime} \mathrm{W}$ & Wet forest & $15-30 \mathrm{~cm}$ & $2004-2013$ & 2004-2005; \\
\hline (2 stands) & $22 \mathrm{~km}$, east & $\begin{array}{c}>3000 \mathrm{~mm} / \text { year } \\
1180 \text { m.a.s.l. }\end{array}$ & $\begin{array}{l}\text { coarse-grained } \\
\text { pumice }\end{array}$ & & 2012-2013 \\
\hline $\begin{array}{l}\text { Paso Córdoba } \\
\text { (2 stands) }\end{array}$ & $\begin{array}{c}40^{\circ} 35^{\prime} \mathrm{S}, 71^{\circ} 08^{\prime} \mathrm{W} \\
81 \mathrm{~km} \text {, east }\end{array}$ & $\begin{array}{c}\text { Dry forest } \\
\sim 800 \text { mm/year } \\
1240 \text { m.a.s.l. }\end{array}$ & $\begin{array}{c}5-10 \mathrm{~cm} ; \\
\text { fine-grained ash }\end{array}$ & 2004-2013 & $\begin{array}{l}\text { 2004-2005; } \\
\text { 2012-2013 }\end{array}$ \\
\hline $\begin{array}{l}\text { Chall-Huaco Valley } \\
\text { (1 stand) }\end{array}$ & $\begin{array}{l}41^{\circ} 13^{\prime}, 71^{\circ} 18^{\prime} \mathrm{W} \\
98 \mathrm{~km} \text {, south-east }\end{array}$ & $\begin{array}{c}\text { Dry forest } \\
\sim 1200 \mathrm{~mm} / \text { year } \\
1050 \text { m.a.s.l. }\end{array}$ & $\begin{array}{c}0.2-1 \mathrm{~cm} ; \\
\text { fine-grained ash }\end{array}$ & 2010-2013 & No data \\
\hline
\end{tabular}

Site geographic coordinates and distance to Volcán Puyehue.

${ }^{2}$ Forest type, mean annual precipitation, and site elevation.

${ }^{3}$ Thickness of the tephra layer deposited on the organic soil horizon, as measured in January 2012.

${ }^{4}$ Sample years with data available for insect herbivory and foliar productivity.

\section{Study sites}

The study was conducted in subalpine forests dominated by Nothofagus pumilio (Poepp. et Endl.) Krasser, a tall deciduous species, which at this latitude forms monospecific stands between 1000-1500 m.a.s.l. (Table 1; Veblen et al. 1996). The regional climate is cold-temperate, with wet winters and dry summers. Precipitation falls as rain and snow, mostly during autumn and winter (April-August), before the start of the main growing season (October-March). The region is characterized by a steep west-to-east precipitation gradient created by the rainshadow of the Andes (Veblen et al. 1996). At the latitude of the study $\left(40^{\circ}-42^{\circ} \mathrm{S}\right)$, total annual precipitation declines from $>3000 \mathrm{~mm}$ near the continental divide to about $800 \mathrm{~mm}$ on the Andean piedmont, $\sim 70 \mathrm{~km}$ east at the ecotone with the Patagonian steppe (Barros et al. 1983). In contrast, mean annual temperatures increase eastward, from $5.6^{\circ} \mathrm{C}$ at Paso Puyehue to $8.4^{\circ} \mathrm{C}$ at Paso Córdoba (Table 1), as recorded in 2010-2011 by $\mathrm{HOBO}^{\circledR}$ data loggers (Onset Comp. Corp., Mass., USA). Soils are poorly developed Andisols derived from recent volcanic deposits (Satti et al. 2003). A thick layer of tephra deposited during the previous eruption (1960) could be found $\sim 10 \mathrm{~cm}$ deep in soils of the Puyehue area (personal observation). Massive ash fall from the June 2011 eruption of VPCC buried the organic soil horizon beneath a new layer of tephra, which varied in depth and texture depending on the latitude and distance to the volcano (Figure 1; Gaitán et al. 2011). Ashes were rich in silicon dioxide $\left(\mathrm{SiO}_{2}\right)$ and aluminum oxide

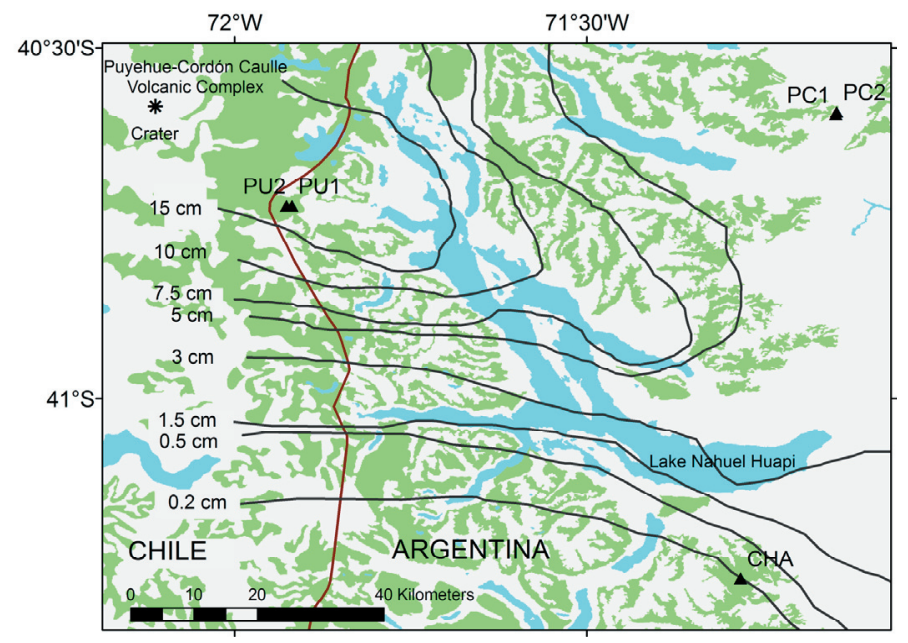

Figure 1. Geographic location of study sites in northern Patagonia, Argentina. Isopachs indicate regionally interpolated thickness values of tephra deposits (redrawn from Gaitán et al. 2011). Note that thickness of ash deposits at the study sites (Table 1) may differ from those expected from the map due to local effects from elevation and landscape configuration. Distribution of Nothofagus pumilio forests is depicted in light green. $\mathrm{PU}=$ Paso Puyehue, $\mathrm{PC}=\mathrm{Paso}$ Córdoba, CHA=Chall-Huaco Valley.

Figura 1. Ubicación geográfica de los sitios de estudio en el norte de la Patagonia, Argentina. Las isolíneas indican niveles de grosor de los depósitos de cenizas obtenidos por interpolación regional (tomado de Gaitán et al. 2011). Nótese que el grosor de la capa de cenizas depositada en los sitios de estudio (Tabla 1) puede diferir de la esperada según el mapa, debido a efectos locales de la elevación y la configuración del paisaje. En verde claro se representa la distribución de los bosques de N. pumilio. PU=Paso Puyehue, PC=Paso Córdoba, CHA=Valle del Chall-Huaco. 
$\left(\mathrm{Al}_{2} \mathrm{O}_{3}\right)$, two compounds with high insecticidal potential (Bermúdez \& Delpino 2011; Buteler et al. 2011). These volcanic glass particles have sharp, irregular edges and high abrasive potential (Bermúdez \& Delpino 2011), which may be lethal to insects (Edwards \& Schwartz 1981).

We studied three N. pumilio forest sites that were differentially affected by the 2011 eruption. Study sites were located at Paso Puyehue (re-named as "Paso Cardenal Samoré"), on the border between Chile and Argentina, and at Paso Córdoba, on the easternmost limit of the N. pumilio distribution (Table 1). Prevalent winds during and after the eruption generated a dispersal 'plume' overlapping with the regional west-to-east precipitation gradient (Figure 1). At the latitude of the volcano (north of Lake Nahuel Huapi), western rainforests received hundreds of tons of sand-sized tephra per hectare, whereas drier forest sites to the east received smaller quantities of fine-grained ash (Bermúdez \& Delpino 2011). Areas located at slightly higher latitudes (south of Lake Nahuel Huapi) received only small amounts of finely ground ash. Our third study site was placed in the Chall-Huaco Valley, which was little affected by ash fall during 2011 (Table 1; Figure 1). In each site, we selected two 1-ha stands for sampling (one stand in ChallHuaco Valley). Stands were embedded within large, continuous forest patches. Study sites were not recently (>100 years) burned and had a well-developed overstorey dominated by oldgrowth N. pumilio. Before the eruption, the woody understorey at Paso Puyehue was made of a thick layer ( $80 \%$ cover) of the evergreen shrub Drymis winteri. The massive fall of sand-sized tephra in this area had a devastating impact on the forest understorey, which was reduced to less than $20 \%$ ground cover. Both living plants and fallen logs were partially buried by a $30 \mathrm{~cm}$-deep mixed layer of coarse-grained pumice and fine ashes, which was rapidly compressed and topped with a hardened surface crust. In Paso Córdoba, neither the shrub understorey (e.g., Berberis spp.) nor the existing herbaceous layer were noticeably damaged by ash deposits. Tree leaves were coated by a thin layer of ash at both the Puyehue and Paso Córdoba sites. Ash has been slowly washed away from trees in the Paso Puyehue rainforest, whereas redistribution of ash particles by windstorms is a very active process in the drier Paso Córdoba area. By contrast, in the Chall-Huaco Valley forest, the understorey dominated by the native lily Alstroemeria aurea remained unaltered, and tree leaves were largely free of volcanic ashes.

\section{Forest canopy productivity}

Forest annual net foliar productivity was measured by collecting the tree leaf litterfall produced throughout the growing season. This method is particularly appropriate for monospecific, deciduous canopies, with a highly synchronised leaf fall at the end of a defined growing season, as in $N$. pumilio forests (Sala \& Austin 2002). Annual foliar production was measured in the Paso Puyehue and Paso Córdoba sites (Table 1), for two growing seasons (2012 and 2013) following the volcanic eruption. These data were compared with those obtained by the same method during the 2004 and 2005 growing seasons (Mazía et al. 2012). Climatic conditions after the eruption (2011-2013) were relatively dry. Total 'effective' precipitation ranged 660-670 mm for the 2012 (May 2011-April 2012) and 2013 (May 2012-April 2013) study seasons, which represented a $20 \%$ decrease relative to the average for the previous 20 years (Bariloche Airport weather station).

In January 2012 (early summer), five litter 'traps' made of $0.44 \mathrm{~m}$-diameter $\times 0.52 \mathrm{~m}$-deep plastic baskets were randomly placed beneath the canopy of each forest stand (two stands/site). A few litter traps were lost from the Paso Córdoba site, so that sample numbers varied between 7-10 traps per site-year. All plant material collected by the traps was removed at the end of the growing season in late May 2012. The same procedure was repeated between January and May 2013; litter traps were re-located at random. Litterfall was not sampled during the winter-spring months, which account for less than $5 \%$ of the annual leaf litter in N. pumilio forests (Caldentey et al. 2001). Tree leaf litter was separated from other materials (twigs, flowers, bark), oven-dried at $60^{\circ} \mathrm{C}$ for $72 \mathrm{~h}$, and weighed to $0.01 \mathrm{~g}$. A sub-sample was taken from each replicate for ash determination (\% litter dry mass, after dry combustion at $550{ }^{\circ} \mathrm{C}$ ). Foliar productivity was expressed in grams of ash-free dry mass $\mathrm{m}^{-2}$ year ${ }^{-1}$.

\section{Herbivory by canopy insects}

Tree foliage was sampled in mid-January and early April of each study season to account for phenological differences among leaf-feeding insects in N. pumilio forests of northern Patagonia (Garibaldi et al. 2010; Mazía et al. 2012). Sampling was performed annually from 2004 to 2013 in the Paso Puyehue and Paso Córdoba sites, and from 2010 to 2013 in the Chall-Huaco Valley site (Table 1). In each forest stand, 10 N. pumilio adult trees ( $>30$ $\mathrm{cm} \mathrm{DBH}$ ) were haphazardly selected; sampled trees were at least $10 \mathrm{~m}$ apart. In the Paso Puyehue and Paso Córdoba sites, selected trees were marked with numbered aluminum tags to allow for repeated sampling over time. In the Chall-Huaco Valley site, sampled trees were not tagged and thus new individuals were chosen every year.

On each sampling date, one fully insolated branch comprising $>100$ leaves was harvested from each tree at $\sim 5-6 \mathrm{~m}$ height using an extensible pole pruner. Insect damage was measured for 30 blindly chosen leaves per branch per date. The proportion of leaf area damaged by insects was measured using a 1$\mathrm{mm}^{2}$ grid (Mazía et al. 2004, 2012). Leaves rarely had more than $75 \%$ of the area missing, which reduced 
the chances that herbivory was underestimated by missing fully eaten leaves (Schowalter 2000). Insect damage was calculated on an individual tree basis, as the total percentage leaf area damaged, which is the total area damaged (out of 30 leaves) divided by the total leaf area sampled $\times 100$ (Williams \& Abbott 1991). Herbivory measures comprised the leaf area damaged by different guilds, including leaf miners, leaf folders, leaf tiers, external chewers and skeletonisers, and gall makers (McQuillan 1993; Mazía et al. 2004, 2012; Garibaldi et al. 2010). Sapsuckers (mainly aphids) were not considered but were quite rare. In our study sites, leaf-mining insects in the Lepidoptera and Hymenoptera were the main feeding guild, with different species forming blotch, linear or serpentine-like mines.

\section{Statistical analyses}

Foliar productivity data were analysed using a nested ANOVA model with type-III sum of squares, including the forest site (Paso Puyehue and Paso Córdoba) and study period (before and after the eruption) as main effects, with the sample year nested within the study period (2004-2005 and 2012-2013). Litterfall traps placed in each forest site were the sample units ( $n=7-10$ per site); stands were not considered in this analysis because of the uneven number of replicates per stand. We performed planned contrasts (with one df) to test for differences in foliage production before vs. after the eruption for each separate forest site. Planned contrasts were also used to test for differences between years after the volcanic event (2012 vs. 2013). This analysis allowed us to examine the initial recovery after ash fall as well as any delayed responses to the event. Litterfall data met the assumptions of normality (residual plots) and variance homogeneity (Levene test $P>0.05$ ).

For the 'temporal analysis' of leaf damage by insects, we used the 10-year data series available for the Paso Puyehue and Paso Córdoba sites (Table 1). In each sample year, total damage values (aggregated over feeding guilds) obtained for January and April were averaged at the individual tree scale before analysis ( $n=10$ trees / stand). We performed a repeated-measures, nested ANOVA (type-III SS), including the forest site as main fixed effect (Paso Puyehue vs. Paso Córdoba), the stands nested within sites as a random effect (two stands per site), and the sample year as the repeated measure. This model accounted for the fact that the same trees within each stand were repeatedly sampled across years. The F-test of the forest site effect used the mean square of the stand (nested within site) effect as error term, while the forest site $\times$ year effect was tested against the residual mean square (Mazía et al. 2012). Data met the sphericity assumption (Mauchley's test). To evaluate differences in leaf area damaged by insects before (2004-2011) vs. after (2012-2013) the eruption, we conducted planned contrasts (one df) for each separate forest site. We also used planned contrasts to test for differences in herbivory levels between post-eruption years (2012 vs. 2013). Here, annual mean damage levels per stand $\left(\mathrm{x}_{\mathrm{i}}\right)$ are shown as standardised deviations (z scores) from the 8-year pre-eruption mean $\left(\mathrm{x}_{\mathrm{m}}\right)$ scaled to standard deviation (SD) units, where $z=\left(x_{i}-x_{\mathrm{m}}\right) / \mathrm{SD}$. This procedure allowed us to compare the relative change in folivory levels between wet and dry forest stands, in the context of background fluctuations recorded before the event.

Lastly, for the 'spatial analysis' of insect folivory, we examined changes in leaf damage through four consecutive years spanning the volcanic event (2010-2013), for two sites that received contrasting amounts of fine-grained ashes (Table 1). We employed a nested ANOVA model with type-III SS, including the forest site (Paso Córdoba and Chall-Huaco Valley) and study period (before and after the eruption) as main effects, with the sample year nested within the study period (2010-2011 and 2012-2013). In this case, we did not conduct a repeated-measures analysis since sampled trees in the Chall-Huaco Valley forest were randomly taken for each annual census. As in previous analyses, we used one-df planned contrasts to evaluate differences in herbivory before vs. after the eruption, and between post-eruption years. Leaf damage data were $\log (x+1)$ transformed to meet the assumptions of ANOVA. All statistical analyses were performed using the General Linear Models (GLM) module of STATISTICA (StatSoft Inc. 2007).

\section{RESULTS}

\section{Foliar productivity}

Tree foliar productivity before the volcanic eruption (2004-2005) was twice as high in the wet forest of Paso Puyehue as in the dry forest of Paso Córdoba. This pattern changed for the two growing seasons following the volcanic event in 2011, as shown by a significant forest site by time period interaction (Table 2, Figure 2). Annual foliar production decreased after the eruption in Paso Puyehue (planned contrast $\left.F_{1,67}=39.6, P<0.0001\right)$, but not in Paso Córdoba $\left(F_{1,67}=1.36, P<0.25\right)$. In the Paso Puyehue forest, foliar productivity was reduced by nearly $60 \%$ during the first growing season post-eruption, relative to pre-eruption records. As a result, differences in productivity between forest sites were no longer apparent after the volcanic eruption (Figure 2).

In addition, there were significant changes in foliar productivity among sample years (Table 2), which mostly reflected an increase in the productivity of both forest sites from 2012 to $2013\left(F_{1,67}=14.21, P<0.001\right)$. These post-eruption 
Table 2. Results of nested ANOVA of annual foliar productivity in Nothofagus pumilio forests affected by the volcanic eruption of June 2011. There were two forest sites located in Paso Puyehue and Paso Córdoba, both sampled before (2004-2005) and after (2012-2013) the eruption. Sample year was nested within time period.

Tabla 2. Resultados del ANOVA de la productividad foliar anual para bosques de Nothofagus pumilio afectados por la erupción volcánica de junio de 2011. Se evaluaron dos sitios localizados en Paso Puyehue y Paso Córdoba, los cuales fueron censados antes (2004-2005) y después (2012-2013) de la erupción. El año del censo quedó anidado dentro del período de tiempo estudiado (antes vs. después).

\begin{tabular}{lcccc}
\hline Source & df & MS & F & P \\
\hline Forest site & 1 & 67332 & 30.00 & 0.0001 \\
Time period $^{1}$ & 1 & 27398 & 1.67 & 0.3251 \\
Site $\times$ period & 1 & 60500 & 26.95 & 0.0001 \\
Year (period) & 2 & 16396 & 7.30 & 0.0014
\end{tabular}

${ }^{1}$ Time period refers to sample years 'before' vs. 'after' the eruption.

changes accounted for a 50\% recovery of foliar productivity to pre-eruption levels in the Paso Puyehue forest, while they represented a net productivity increase in the Paso Córdoba forest (Figure 2).

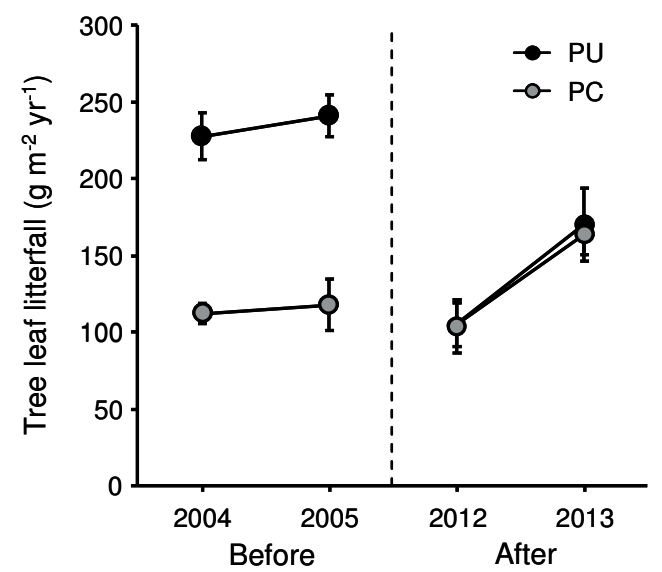

Figure 2. Annual foliar productivity of Nothofagus pumilio forests before and after the volcanic eruption of June 2011. Foliar production was measured as total leaf litterfall (g ash-free dry mass. $\mathrm{m}^{-2}$.year ${ }^{-1}$ ) during a growing season. Data show means $\pm \mathrm{SE}$ ( $n=8$-10 litter traps), for a wet forest at Paso Puyehue (black circles) and a dry forest at Paso Córdoba (grey circles), which were covered by coarse- and fine-grained tephra, respectively (see Table 1)

Figura 2. Productividad foliar anual en bosques de Nothofagus pumilio antes y después de la erupción volcánica de junio 2011. La productividad fue medida como la cantidad total de hojarasca caída durante la estación de crecimiento ( $\mathrm{g}$ masa seca libre de cenizas.m ${ }^{-}$ ${ }^{2}$. año $\left.^{-1}\right)$. Los datos muestran el promedio \pm SE $(n=8-10$ trampas), para un bosque lluvioso en Paso Puyehue (símbolos negros) y un bosque seco en Paso Córdoba (símbolos grises), cubiertos por cenizas gruesas y finas, respectivamente (ver Tabla 1).

\section{Insect herbivory: temporal analysis}

Leaf area damaged by insects differed markedly between forest sites before the 2011 event. Herbivory levels were an order of magnitude higher in the dry forest of Paso Córdoba than in the wet forest of Paso Puyehue (rmANOVA, forest site: $F_{1,2}=153.9$, $P<0.00001$; Figure 3a, b). Mean annual'damage per forest stand ranged between $1.2 \%$ and $6 \%$ in Paso Puyehue, and between $15 \%$ and $37 \%$ in Paso Córdoba. Leaf mining (mostly Hymenoptera: Tenthredinidae) and leaf tying (Lepidoptera: Gellechiidae) insects were the main feeding guilds in the dry forest, whereas external feeders including leaf chewers and skeletonisers (Lepidoptera: Saturniidae, Geometridae and Noctuidae; Coleoptera: Curculionidae) dominated in the wet forest.

Insect herbivory fluctuated strongly among years, depicting a temporal pattern that depended on the forest site (site $\times$ year: $F_{9,342}=46.9, P<0.00001$; Figure $\left.3 a, b\right)$. Before the eruption, inter-annual fluctuations in leaf damage were bound within \pm 2 SD around the long-term mean for both forest sites (Figure 3c, d). After the eruption, herbivory levels dropped to the lowest point recorded throughout the 10-year time series. Leaf damage was significantly lower after the eruption (2012-2013) than before the eruption (2004-2011) in both forest sites (planned contrasts $P<0.00001$ ). Leaf area loss to insects decreased below $1 \%$ during the first season post-eruption (see Figure 3a, b). Folivorous insects were virtually wiped out from the forest canopy of both study sites, with all major feeding guilds being equally affected (data not shown).

The post-eruption (2012) decrease in herbivory represented a smaller deviation from the long-term mean in the Paso Puyehue forest ( -1.35 and -1.49 SD units; Figure 3c) than in the Paso Córdoba forest (-2.42 and -3.29 SD units; Figure 3d). Nevertheless, insect damage after the eruption was significantly smaller than the lowest values on record before the eruption, both in Paso Puyehue (contrast 2007-2008 vs. 2012-2013: $F_{1,36}=203.5, P<0.00001$; Figure 3c) and in Paso Córdoba (2008 vs. 20122013: $F_{1,36}=25.5, P<0.0001$; Figure 3d).

Insect herbivory exhibited a small, but significant, recovery between 2012 and 2013 in the Paso Córdoba forest $\left(F_{1,36}=136.3\right.$, $P<0.00001$; Figure 3b). Still, leaf damage for 2013 remained below pre-eruption 

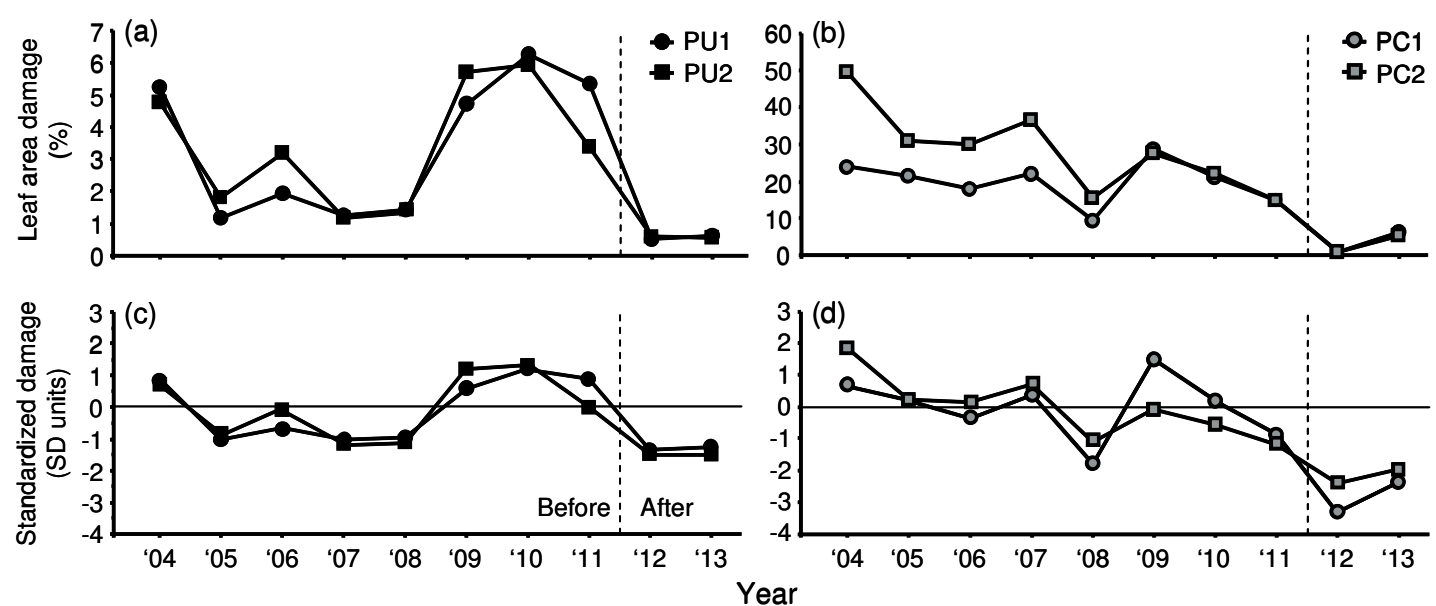

Figure 3. Temporal variation of leaf herbivory in (a, c) two rainforest stands at Paso Puyehue (PU1, PU2), and (b, d) two dry forest stands at Paso Córdoba (PC1, PC2). Time series with different symbols correspond to different stands ( $n=2$ stands/site). Each data point is the mean of 10 trees/stand. Herbivory levels are shown as $(a, b)$ percentage leaf area damaged by insects, and (c, d) standardized annual deviations from the pre-eruption average damage, scaled to standard deviation (SD) units. Data were taken before and after the eruption of June 2011 (dashed line). Mean leaf area damage (2004-2011) was PU1 $=3.4 \%$, PU2 $=3.4 \%, \mathrm{PC} 1=20 \%$, PC2 $=28.4 \%$.

Figura 3. Variación temporal de la herbivoría foliar en el dosel de $(\mathrm{a}, \mathrm{c})$ de dos rodales de bosque lluvioso en Paso Puyehue (PU1, PU2) y (b) dos rodales de bosque seco en Paso Córdoba (PC1, PC2). Series de tiempo con símbolos distintos representan diferentes rodales ( $n=2 \mathrm{rodal} / \mathrm{sitio}$ ). Cada dato es el promedio de 10 árboles/rodal. La herbivoría está representada por $(\mathrm{a}, \mathrm{b})$ el porcentaje de área foliar dañada por insectos y $(\mathrm{c}, \mathrm{d})$ las desviaciones anuales del promedio de daño foliar pre-erupción, expresadas en unidades de desvío estándard. Las mediciones fueron realizadas antes y después de la erupción de junio 2011 (línea punteada).

levels (-2.2 SD units; Figure 3d). Insect recovery was driven by leaf mining sawflies (Tenthredinidae), the dominant folivores in Paso Córdoba. In contrast, in the Paso Puyehue forest, herbivory levels showed no clear sign of recovery within two years from the event (2012 vs. 2013: $F_{1,36}=0.24, P<0.63$; Figure 3a).

Table 3. Results of nested ANOVA of leaf area damaged by folivorous insects in Nothofagus pumilio forests affected by the volcanic eruption of June 2011. The analysis compared two forest sites located in Chall-Huaco Valley and Paso Córdoba, both sampled during four consecutive growing seasons, before (2010-2011) and after (2012-2013) the eruption. Sample year was nested within time period. Data were $\log (\mathrm{x}+1)$ transformed.

Tabla 3. Resultados del ANOVA del área foliar dañada por insectos folívoros en bosques de Nothofagus pumilio afectados por la erupción volcánica de junio 2011. El análisis comparó dos sitios localizados en el Valle del Chall-Huaco y Paso Córdoba, los cuales fueron censados durante cuatro años consecutivos, antes (2010-2011) y después (2012-2013) de la erupción. El año del censo quedó anidado en el período de tiempo (antes vs. después). Datos transformados por el $\log (\mathrm{x}+1)$.

\begin{tabular}{lcccc}
\hline Source & df & MS & F & P \\
\hline Forest site & 1 & 0.037 & 1.66 & 0.2007 \\
Time period $^{1}$ & 1 & 1.674 & 1.20 & 0.3879 \\
Site $\times$ period & 1 & 6.444 & 291.81 & 0.0001 \\
Year(period) & 2 & 1.397 & 63.26 & 0.0001 \\
Residual error & 114 & 0.022 & & \\
\hline 1Timeperiod refers to & & & \\
\hline
\end{tabular}

${ }^{1}$ Time period refers to sample years 'before' vs. 'after' the eruption.

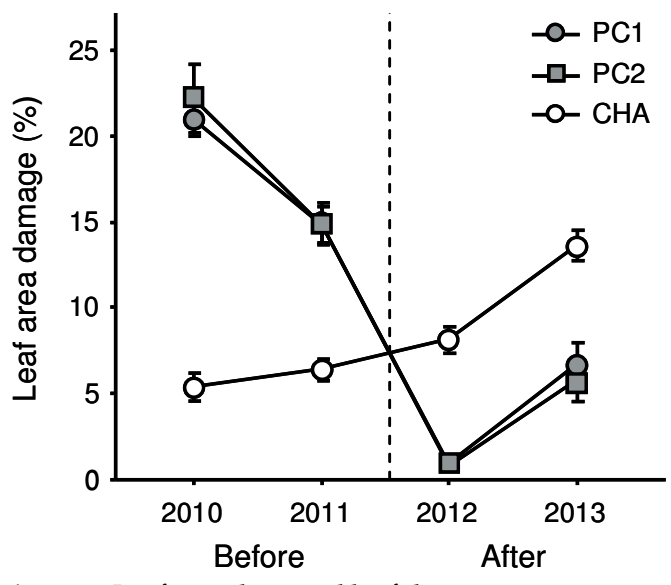

Figure 4. Leaf area damaged by folivorous insects in two dry forest stands at Paso Córdoba (PC1, PC2) and a dry forest stand at Chall-Huaco Valley (CHA), before and after the volcanic eruption of June 2011 (dashed line). The PC stands were heavily affected by ash fall, whereas the CHA forest was not. Symbols represent different stands within a forest site. Each data point is the mean \pm SE of 10 trees per stand.

Figura 4. Área foliar dañada por insectos folívoros en el dosel de dos rodales de bosque seco afectados por cenizas en Paso Córdoba (PC1, PC2) y en un rodal de bosque seco no afectado por cenizas en el Valle del Chall-Huaco (CHA), antes y después de la erupción de junio 2011 (línea punteada). Los símbolos representan distintos stands en un mismo sitio de estudio. Cada dato es el promedio $\pm \mathrm{SE}$ de 10 árboles por rodal. 


\section{Insect herbivory: spatial analysis}

Herbivory levels measured in the Paso Córdoba forest before and after the eruption were compared to those taken at the ChallHuaco Valley forest, which received little volcanic ash (Table 1, Figure 1). We found a highly significant site by time interaction (Table 3), which indicated that patterns of leaf area damage before vs. after the eruption depended on the forest site (Figure 4). Whereas leaf damage in Paso Córdoba was drastically reduced after the eruption (planned contrast, $\left.F_{1,114}=498, P<0.00001\right)$, herbivory levels in the Chall-Huaco Valley tended to increase, relative to those before the event $\left(F_{1,114}=26.32\right.$, $P<0.00001)$. The latter response was driven by the increased frequency of mining moths forming linear-shaped mines (Lepidoptera: Gracillaridae). As a result, existing differences in herbivory between forest sites were reversed after the volcanic event (Figure 4). In addition, leaf damage significantly differed between sample years before and after the eruption. Intriguingly, herbivory levels increased from 2012 to 2013 in both the Paso Córdoba and Chall-Huaco forests $\left(F_{1,114}=122.3, P<0.00001\right.$; Figure 4).

\section{DISCUSSION}

Our temporal and spatial analyses illustrate how volcanic events can exert substantial impacts on ecosystem processes over wide areas of forest, even if canopy tree species do not suffer mass mortality. Results were consistent with the notion that effects from ash fall varied with site distance to the crater and the process being studied (see also Dale et al. 2005). Foliar production dropped abruptly after the 2011 eruption in the wet forest near the VPCC crater, but did not change in the dry forest farther away from the crater. In contrast, leaf damage by insects generally decreased with heavy ash fall, although the effect was most pronounced in the dry forest, which sustained the highest folivory rates. As a result, pre-existing differences in productivity and herbivory between these contrasting forest sites were temporarily erased (Figure 2,3). In the short term, volcanic ash deposition reduced the energy flow through the forest canopy and its arthropod consumer community.

\section{Changes in canopy productivity}

As expected from the huge amount of tephra deposited within a $\sim 20 \mathrm{~km}$ radius from the crater, tree foliage production markedly decreased in the Paso Puyehue forest after the eruption. Yet, the exact mechanism behind this effect is not known. Most ash fall occurred during winter and early spring, well before bud burst takes place in N. pumilio canopies. It seems therefore plausible that the observed decrease in foliar productivity was partly caused by bud mortality, which could have been induced by either physical or chemical damage from tephra ejected during the early phase of the eruption (Seymour et al. 1983; Antos \& Zobel 2005). Mechanical damage to tree crowns produced by heavy, sand-sized ash fall could have reduced the total number of leaf buds (cf. Lawrence 2005), whereas there was no evidence from scorched buds that ash temperatures were high enough to damage plants. On the other hand, leachate of toxic compounds from water-dissolved tephra may create 'acid rain' (ver Bermúdez \& Delpino 2011), which migh have been responsible for killing hectares of Nothofagus forest closer to the crater in Chile. Several works have reported decreased tree radial growth with tephra fall after major volcanic events (e.g., Yamaguchi 1983; Segura et al. 1995; Biondi et al. 2003), although causal mechanisms have rarely been identified.

Importantly, the impact of ash deposition on foliar production carried over through the second year after the eruption. Although we recorded a substantial recovery for the 20122013 season, leaf litterfall in Paso Puyehue remained well below that measured in preeruption years (Figure 2). Trees may recover from partial crown dieback by allocating resources to new growing points, a process that in deciduous species like $N$. pumilio may increase foliar production the year following the disturbance (Kozlowski et al. 2001). However, a lag in recovery of pre-eruption productivity would be expected due to the decline in photosynthetic leaf area and the resulting drop in current-year carbon fixation (i.e., a 'source' limitation to regrowth). Tree foliage recovery may be also delayed by differentiation of new buds after disturbance (a 'sink' limitation to regrowth; see Kozlowski et al. 2001). While physiological responses of ash-laden Nothofagus trees are yet to be studied, our data show that tephra deposition can have lasting effects on whole-canopy productivity of forest stands located outside the 'kill zone' (Seymour et al. 1983; Antos \& Zobel 2005).

We did not detect a net significant change in foliar production immediately after the 
eruption at the Paso Córdoba site. If the finegrained ash deposited on the eastern forests did have any damaging effect on bud numbers, it would have been counteracted by indirect effects such as reduced insect herbivory and, perhaps, enhanced soil conditions. Indeed, both these factors might help to explain the $50 \%$ increase in foliar productivity observed during the second year post-eruption in Paso Córdoba (see Figure 2). In dry N. pumilio forests, folivorous insects can remove up to $20 \%$ of the annual foliar production (Mazía et al. 2012). Insect damage also causes premature leaf abscission (Mazía et al. 2012), further reducing the photosynthetic capacity of trees (Schowalter 2000). Thus, a major decline in folivory levels (Figure 3b, d) may have a large positive influence on annual foliage production.

Changes in forest soil conditions under heavy ash fall are potentially complex. Soil evaporation rates would decrease under thick deposits of fine-grained tephra, which should increase water availability to trees during the summer (Marske et al. 2007; Milani, Rodríguez \& Kitzberger, unpublished data). This effect may be important for tree growth in drier forest sites and during low-precipitation years, like those following the 2011 eruption in northern Patagonia. Ash layers may increase albedo, which should reduce soil heating but may also lead to higher transpiration rates (Black \& Mack 1986). In contrast, a short-term 'fertilisation' effect from ash deposits seems less likely, given the composition of tephra ejected by the VPCC system (Bermúdez \& Delpino 2011). It will be interesting to see whether the increased productivity we report for Paso Córdoba persists over the next few years (see Biondi et al. 2003). We speculate that it might depend on the extent of the suppressive effect of volcanic ash on insect herbivory, and the potential increase of soil fertility with weathering of ash deposits in contact with fresh organic matter (Dahlgren et al. 2004).

\section{Changes in canopy insect herbivory}

We found that insect folivory decreased abruptly after the volcanic event in our longterm study sites. Leaf damage levels for the 2011-2012 season fell outside the historical range of interannual variation recorded before the eruption. The amount of leaf area damaged by insects in N. pumilio forests can vary substantially among years, reflecting the influence of climate fluctuation on major feeding guilds (Mazía et al. 2004, 2009; Paritsis \& Veblen 2011). However, the posteruption decrease of insect folivory was more pronounced than the lowest values observed during a relatively cool period in 2007-2008. Comparison of leaf damage between Paso Córdoba and Chall-Huaco Valley (Figure 4) further suggests that the extremely low herbivory we found in ash-affected forests represented an extraordinary condition (cf. Marske et al. 2007). Ash deposition appeared to exert a large-scale, broad-spectrum insecticidal effect on forest canopy herbivores.

While the intensity of ashfall declined with distance to the crater, the relative impact on insect herbivory was greater for the dry forest at Paso Córdoba than for the wet forest at Paso Puyehue (Figure 3). This pattern followed pre-existing differences between study sites in endemic folivory rates. In the dry forest, most foliar damage is caused by leaf mining and leaf tying insects, which exhibit a clear seasonal niche separation (Mazía et al. 2012). Major leaf miners (sawflies) emerge in early October and colonise the forest canopy before December, while leaf-tying moths colonise trees from late January onwards. Last-instar larvae vacate $N$. pumilio leaves during January and April, respectively, and overwinter as pupae in the topsoil. After the eruption, the pupae of both dominant feeding guilds at Paso Córdoba were probably buried under a thick layer of fine ashes, which would have greatly reduced their survivorship to the next season. Insect herbivores that managed to escape burial would have been affected by contact with ash particles, which may cause damage by abrasion and desiccation (Edwards \& Schwartz 1981; Buteler et al. 2011).

By contrast, in the wet forest at Paso Puyehue most damage on N. pumilio was produced by external, leaf-chewing caterpillars that lay eggs in small twigs and understorey plants. In these forests, insect folivory is chronically low, except for transient peaks occurring after unusually warm and dry years (Mazía et al. 2009). Yet in this forest the amount of leaf area removed by insects after the eruption was virtually nil. This effect could partly reflect the decrease in leaf area associated with heavy tephra fall. In addition, direct physical or chemical damage to egg clumps and early-instar larvae (Buteler et al. 2011), as well as the disruption of larval feeding by ash deposition on leaf surfaces (Edwards \& 
Schwartz. 1981; Marske et al. 2007), represent other mechanisms whereby ashfall might cause the collapse of insect folivory in forest canopies.

Data collected two years after the eruption revealed a differential pattern for early recovery of insect herbivory in our long-term study sites. In the Paso Córdoba forest, leaf damage in 2013 increased relative to the first post-eruption year, although it remained well below the pre-eruption average (Figure $3 b$ ). It is unclear whether folivorous insects recolonised from local refugia or by immigration from other forest patches less affected by ash fall. Possibly, insect larvae surviving the initial disturbance managed to find ash-free microsites to pupate, before a new litter layer began to build up in autumn 2013. Recovery of insect herbivory levels may be also facilitated by a relaxation of top-down controls from parasitoids and avian predators (Bishop et al. 2005; Marsk et al. 2007; Garibaldi et al. 2010). We have evidence for the Paso Córdoba forest that parasitism rates on leaf miners were strongly reduced after the 2011 eruption, and had not fully recovered by 2013 (Chaij et al., unpublished data). Work during primary succession on Mount St. Helens has shown that recovery of insect populations after major volcanic disturbances can be highly spatially heterogeneous, being influenced by multiple abiotic and biotic factors (Fagan \& Bishop 2000; Bishop et al. 2005; Parmenter et al. 2005; Yang et al. 2011)

There was little evidence of an early recovery in insect herbivory in the Paso Puyehue forest site. We have previously suggested that prevailing abiotic conditions would be too harsh for canopy insects in the cool-wet $N$. pumilio forests of the Andean subalpine zone (Mazía et al. 2004, 2012; Garibaldi et al. 2010). Chronic limitations to herbivorous insect densities were compounded by the massive deposition of coarse and fine tephra in 2011. Hence, in these wet forests, folivorous insects would have to recover from extremely small, remnant populations. Under this scenario, we reason that many insect species could only recolonise from distant areas outside the ash plume (Bishop et al. 2005). Post-eruption immigration rates would be highly dependent on species life-history traits, with large-bodied lepidopteran moths (e.g., Ormiscodes spp.) having a potential advantage (Schowalter 2000). Nevertheless, we noticed that the local redistribution of fine ashes by wind currents may extend their presence on leaf surfaces, thus increasing the exposure of canopy insects long after the actual ashfall event (Inbar et al. 1995; Marske et al. 2007). This effect may persist for several years and would contribute to delay the system's return to pre-eruption folivory levels. In the light of these results, we hypothesise that the chronically low endemic herbivory found in N. pumilio wet forests may, at least partly, result from relatively frequent and severe volcanic disturbances on insect communities.

\section{Implications for forest ecosystem functioning}

Our results show a widespread disruption of forest canopy-herbivore interactions in areas affected by heavy ash deposition. In our study sites, the realised severity of ashfall disturbance was dependent on preexisting site conditions and the process being considered. The differential changes in foliar productivity and insect herbivory recorded in this study would have varying consequences on forest ecosystem function. In subalpine wet forests close to the VPCC system, decreased foliar production should constrain leaf litter inputs to the soil, which may slow the process of organic carbon formation on new volcanic substrate. Conversely, in drier forest sites covered by the ash plume, decreased canopy herbivory together with the (transient) increase in foliar production would facilitate the addition of fresh organic matter to the volcanic substrate. Insect herbivory may also influence carbon and nutrient cycling at the soil level by altering litter decomposition rates (Hunter 2001; Hartley \& Jones 2004). Therefore, recovery of folivore communities may be critical to the long-term impact of volcanic eruptions in these forests. At present, however, we lack the data to understand the full temporal scale of ecosystem effects elicited by ashfall in Patagonia. This limitation highlights the importance of monitoring the effects of extreme events through long-term studies focusing on multi-trophic communities and key ecosystem processes.

In conclusion, we have documented major changes in foliar production and insect herbivory in subalpine $N$. pumilio forests affected by volcanic ash deposition after the recent eruption of VPCC system. Remarkably, volcanic ashes acted as a natural insecticide on a regional scale, drastically reducing tree leaf damage from different insect guilds, even in forest stands outside the kill zone 
and distanced tens of kilometers from the crater. Our findings underscore the need to further examine how large-scale volcanic events influence ecosystem function in the Patagonian Andes.

Acknowledgements: We are grateful to all the students that helped with sample collection during this project. We also thank the National Parks Administration of Argentina and the owners of "Estancia Chacabuco del Neuquén" for granting the access to the field sites. Comments from two anonymous reviewers helped to improve the manuscript. This work was partly funded by Agencia Nacional de Promoción Científica y Tecnológica (BID-PICT Redes 0331 and 0284) and the University of Buenos Aires.

\section{REFERENCES}

Antos, JA \& DB ZoBeL. 2005. Plant responses in forests of the tephra-fall zone. Pp. 47-58 in: Dale, VH; FJ Swanson \& CM Crisafulli (eds.). Ecological Responses to the 1980 Eruption of Mount St. Helens. Springer, New York.

Bermúdez, A \& D Delpino. 2011. La actividad del volcán Puyehue y su impacto sobre el territorio de la República Argentina. Informe Técnico. Universidad Nacional del Comahue, S.C. Bariloche. Pp. 16.

Biondi, F; I Galindo Estrada; JC Gavilanes Ruiz \& AE TORRES. 2003. Tree growth response to the 1913 eruption of Volcán de Fuego de Colima, Mexico. Quat. Res., 59: 293-299.

Bishop, JG; WF William; JD Schade \& CM CRisafulli. 2005. Causes and consequences of herbivory on prairie lupine (Lupinus lepidus) in early primary succession. Pp. 151162 in: Dale, VH; FJ Swanson \& CM Crisafulli (eds.). Ecological Responses to the 1980 Eruption of Mount St. Helens. Springer, New York.

Buteler, M; T Stadler; GP López García; MS Lassa; D Trombotto Lliaudat; et al. 2011. Propiedades insecticidas de la ceniza del complejo volcánico Puyehue-Cordón Caulle y su posible impacto ambiental. Rev. Soc. Entomol. Arg., 70:149-156.

Caldentey, J; M IbarRa \& J Hernández. 2001. Litter fluxes and decomposition in Nothofagus pumilio stands in the region of Magallanes, Chile. For. Ecol. Manag., 148:145-157.

DAhlgren, RA; M SAigusa \& FC Ugolini. 2004. The nature, properties and management of volcanic soils. Adv. Agro., 82:113-182.

Dale, VH; FJ Swanson \& CM CRisafulli. Eds. 2005. Ecological Responses to the 1980 Eruption of Mount St. Helens. Springer, New York.

EDWARDS, JS \& LM SchwarTz. 1981. Mount St. Helens ash: a natural insecticide. Can. J. Zool., 59:714-715.

FAGAN, WF \& JG BISHOP. 2000. Trophic interactions during primary succession: herbivores slow a plant reinvasion at Mount St. Helens. Am. Nat., 155:238-251.

FRANKLIN, JF; PM FRENZEN \& FJ SWANSON. 1995. Re-creation of ecosystems at Mount St. Helens: contrasts in artificial and natural approaches. Pp. 287-333 in: Cairns Jr, J (ed.). Rehabilitating Damaged Ecosystems. CRC Press, Boca Raton, Florida.

Gattán, Jj; JA Ayesa; F Umaña; F RafFo \& DB Bran. 2011. Cartografía del área afectada por cenizas volcánicas en las provincias de Río Negro y Neuquén. Informe Técnico. Laboratorio de Teledetección-SIG, INTA-EEA S. C. Bariloche.

Garibaldi, LA; T Kitzberger; CN Mazía \& EJ Chaneton. 2010. Nutrient supply and bird predation additively control insect herbivory and tree growth in two contrasting forest habitats. Oikos, 119:337-349.

HARTLEY, SE \& TH JONES. 2004. Insect herbivores, nutrient cycling and plant productivity. Pp. 27-52 in: Weisser, WW \& E Siemann (eds.). Insects and Ecosystem Function. Springer-Verlag, Berlin.

HinCKLEY, TM; H IMOTO; K LeE; S LACKer; Y MORIKAWA; ET AL. 1984. Impact of tephra deposition on growth in conifers: the year of the eruption. Can. J. For. Res., 14:731-739.

HunTER, MD. 2001. Insect population dynamics meets ecosystem ecology: effects of herbivory on soil nutrient dynamics. Agric. For. Entom., 3:77-84.

HUNTER, MD \& PW PRICE. 1992. Playing chutes and ladders: heterogeneity and the relative roles of bottom-up and top-down forces in natural communities. Ecology, 73: 724-732.

Inbar, M; HA Ostera; CA Parica; MB Remesal \& FM SAlan. 1995. Environmental assessment of 1991 Hudson volcano eruption ashfall effects on southern Patagonia region, Argentina. Envir. Geol., 25:119-125.

KitZberger, T. 2012. Impact of extreme and infrequent events on terrestrial ecosystems and biodiversity. Pp. 209-223 in: Levin, SA (ed.). Encyclopedia of Biodiversity, $2^{\text {nd }}$ Edition. Elsevier, Amsterdam.

Kozlowski, T; P Kramer \& S Pallardy. 1991. The Physiological Ecology of Woody Plants. Academic Press, New York.

LAWRENCE, R. 2005. Remote sensing of vegetation responses during the first 20 years following the 1980 eruption of Mount St. Helens: a spatially and temporally stratified analysis. Pp. 111-126 in: Dale, VH; FJ Swanson \& CM Crisafulli (eds.). Ecological Responses to the 1980 Eruption of Mount St. Helens. Springer, New York.

LINDENMAYER, DB; GE LiKENS \& JF FRANKLIN. 2010. Rapid responses to facilitate ecological discoveries from major disturbances. Front. Ecol. Envir., 8:527-532.

MarsKe, KA; MA Ivie \& GM Hilton. 2007. Effects of volcanic ash on the forest canopy insects of Montserrat, West Indies. Envi. Entomol., 36:817-825.

MAZÍA, CN; T KitZBERGer \& EJ CHANETON. 2004. Interannual changes in folivory and bird insectivory along a natural productivity gradient in northern Patagonian forests. Ecography, 27:29-40.

Mazía, CN; EJ Chaneton; T Kitzberger \& LA Garibaldi. 2009. Variable strength of top-down effects in Nothofagus forests: bird predation and insect herbivory during an ENSO event. Austr. Ecol., 34:357-367.

Mazía, N; EJ Chaneton; C Dellacanonica; L Dipaolo \& T KITZBERGER. 2012. Seasonal patterns of herbivory, leaf traits, and productivity consumption in dry and wet Patagonian forests. Ecol. Entom., 37:193-203.

McQuillan, PB. 1993. Nothofagus (Fagaceae) and its invertebrate fauna - an overview and preliminary synthesis. Biol. J. Linn. Soc. Lon., 49:317-54.

Paritsis, J \& TT Veblen. 2011. Dendroecological análisis of defoliator outbreaks on Nothofagus pumilio and their relation to climatic variability in the Patagonian Andes. Global Change Biol., 17:239-253.

Parmenter, RR; CM CRISAFulli; NC Korbe; GL PARsons; MJ 
KREUTZIAN; ET AL. 2005. Posteruption arthropod succession on the Mount St. Helens Volcano: the ground-dwelling beetle fauna (Coleoptera). Pp. 139-150 in: Dale, VH; FJ Swanson \& CM Crisafulli (eds.). Ecological Responses to the 1980 Eruption of Mount St. Helens. Springer, New York.

SAla, OE \& AT Austin. 2002. Methods of estimating aboveground net primary productivity. Pp. 31-43 in: Sala, OE; RB Jackson, HA Mooney \& RH Howarth (eds.). Methods in Ecosystem Science. Springer, New York.

Schowalter, TD. 2000. Insect Ecology: An Ecosystem Approach. Academic Press, San Diego, California.

Segura, G; TM Hinckley \& CD Oliver. 1995. Stem growth responses of declining mature Abies amabilis trees after tephra deposition from Mount St. Helens. Can. J. For. Res., 25:1493-1502.

SмIтH, M. 2011. An ecological perspective on extreme climatic events: a synthetic definition and framework to guide future research. J. Ecol., 99:656-663.

SPILLER, DA \& TW Schoener. 2007. Alteration of food-web dynamics following major disturbance by hurricanes. Ecology, 88:37-41.

Stewart-Oaten, A; WW Murdoch \& KR Parker. 1986. Environmental impact assessment: pseudoreplication in time? Ecology, 67:929-940.

StatSoft, Inc. 2007. STATISTICA, Data Analysis Software System. Ver. 8.0. Tulsa, Oklahoma.

SEYMOUR, VA; TM HINCKLEY; Y MORIKAWA \& JF FRANKLIN. 1983. Foliage damage in coniferous trees following volcanic ashfal from Mt. St. Helens. Oecologia, 59:339-343.

Turner, MG; VH Dale \& EH Everham, III. 1997. Fires, hurricanes and volcanoes: comparing large disturbances. BioScience, 47:758-768.

UNDERWOOD, AJ. 1992. Beyond BACI: the detection of environmental impacts on populations in the real, but variable, world. J. Exp. Mar. Biol. Ecol., 161:145-178.

VeBLEn, TT. 1985. Stand dynamics in Chilean Nothofagus forests. Pp. 35-52 in: Pickett, STA \& PS White (eds.). The Ecology of Natural Disturbance and Patch Dynamics. Academic Press, Orlando, Florida.

Veblen, TT; C Donoso; T Kitzberger \& A Rebertus. 1996. Ecology of southern Chilean and Argentinean Nothofagus forest. Pp. 293-353 in: Veblen, TT; R Hill \& J Read (eds.). The Ecology and Biogeography of Nothofagus Forests. Yale University Press, New Haven.

White, PS \& STA PICKeTt. 1985. Natural disturbance and patch dynamics: an introduction. Pp. 3-16 in: Pickett, STA \& PS White (eds.). The Ecology of Natural Disturbance and Patch Dynamics. Academic Press, Orlando, Florida.

Williams, MR \& I Аввотт. 1991. Quantifying average defoliation using leaf-level measurements. Ecology, 72: 1510-1511.

YAMAGUCHI, DK. 1983. New tree-ring dates for recent eruptions of Mount St. Helens. Quat. Res., 20:246-250.

YanG, S; E Jongejans; S Yang \& JG BisHor. 2011. The effect of consumers and mutualists of Vaccinium membranaceum at Mount St. Helens: dependence on successional context. PloS ONE, 6:e26094.

ZoBel, DB \& JA Antos. 1997. A decade of recovery of understory vegetation buried by volcanic tephra from Mount St. Helens. Ecology, 67:317-344. 